\title{
Evaluation of potential genetic and chemical markers for Scots pine tolerance against Heterobasidion annosum infection
}

\author{
Mukrimin Mukrimin $^{1,2} \cdot$ Andriy Kovalchuk $^{1} \cdot$ Rajendra P. Ghimire $^{3} \cdot$ Minna Kivimäenpää $^{3} \cdot$ Hui Sun ${ }^{1,4}$. \\ Jarmo K. Holopainen ${ }^{3}$. Fred O. Asiegbu' ${ }^{1}$ (D
}

Received: 30 May 2019 / Accepted: 27 August 2019 / Published online: 4 September 2019

(c) The Author(s) 2019

\begin{abstract}
Main conclusion Two terpene compounds and four genes were identified as potential biomarkers for further evaluation for Scots pine susceptibility or tolerance against Heterobasidion annosum.
\end{abstract}

\begin{abstract}
Scots pine (Pinus sylvestris) is one of the main sources of timber in the boreal zone of Eurasia. Commercial pine plantations are vulnerable to root and butt rot disease caused by the fungus Heterobasidion annosum. The pathogen affects host growth rate, causes higher mortality and decreases in timber quality, resulting in considerable economic losses to forest owners. Genetic and biochemical factors contributing to Scots pine tolerance against $H$. annosum infection are not well understood. We assessed the predictive values of a set of potential genetic and chemical markers in a field experiment. We determined the expression levels of 25 genes and the concentrations of 36 terpenoid compounds in needles of 16 Scots pine trees randomly selected from a natural population prior to artificial infection. Stems of the same trees were artificially inoculated with H. annosum, and the length of necrotic lesions was documented 5 months post inoculation. Higher expression level of four genes included in our analysis and encoding predicted $\alpha$-pinene synthase (two genes), geranyl diphosphate synthase (GPPS), and metacaspase 5 (MC5), could be associated with trees exhibiting increased levels of necrotic lesion formation in response to fungal inoculation. In contrast, concentrations of two terpenoid compounds, $\beta$-caryophyllene and $\alpha$-humulene, showed significant negative correlations with the lesion size. Further studies with larger sample size will help to elucidate new biomarkers or clarify the potential of the evaluated markers for use in Scots pine disease resistance breeding programs.
\end{abstract}

Keywords Chemical defences $\cdot$ Gene expression $\cdot$ Heterobasidion $\cdot$ Root rot disease $\cdot$ Scots pine $\cdot$ Terpenoid

Electronic supplementary material The online version of this article (https://doi.org/10.1007/s00425-019-03270-8) contains supplementary material, which is available to authorized users.

Fred O. Asiegbu

fred.asiegbu@helsinki.fi

1 Department of Forest Sciences, Faculty of Agriculture and Forestry, University of Helsinki, Latokartanonkaari 7, P.O. Box 27, 00014 Helsinki, Finland

2 Department of Forestry, Faculty of Forestry, Hasanuddin University, Jln. Perintis Kemerdekaan Km. 10, 90245 Makassar, Indonesia

3 Department of Environmental and Biological Sciences, Kuopio Campus, University of Eastern Finland (UEF), P.O. Box 1627, 70211 Kuopio, Finland

4 Collaborative Innovation Center of Sustainable Forestry in Southern China, College of Forestry, Nanjing Forestry University, Nanjing, China

\author{
Abbreviations \\ GPPS Geranyl diphosphate synthase \\ MC5 Metacaspase 5 \\ PCD Programmed cell death \\ PCoA Principal coordinates analysis \\ PERMANOVA Permutational multivariate analysis of \\ variance
}

\section{Introduction}

Scots pine (Pinus sylvestris L.) is a dominant tree species, occupying 64\% of Finnish land area, and the largest growing stock, reaching 1157 million $\mathrm{m}^{3}$. It is a species of major economic importance, widely used in timber, pulp, and paper production (Metla 2013). A health status of Scots pine trees is an essential prerequisite for the sustainable timber production. In fact, potential threats to Scots pine stands include 
both biotic (e.g., pathogenic fungi, bacteria and nematodes, herbivorous insects and mammals, natural competition, and human interference), and abiotic factors (e.g., drought, windfall, etc.) (Metla 2013). The dynamics of forest ecosystems, including their productivity and economic value, is significantly affected by fungal pathogens. In Northern Hemisphere forests, fungi comprising Heterobasidion annosum s.l. species complex cause root-rot disease of conifer trees (Asiegbu et al. 2005). The trees infection by H. annosum, which attacks the sapwood and kills the vascular cambium, causes decreased growth and timber quality, and eventually leads to mortality of trees (Swedjemark and Stenlid 1995; Oliva et al. 2011; Gori et al. 2013).

The species $H$. annosum, $H$. parviporum, and $H$. abietinum are European representatives of the species complex $H$. annosum s.l., attacking particular conifer hosts comprising Scots pine, Norway spruce (Picea abies), and silver fir (Abies alba), respectively (Asiegbu et al. 2005; Garbelotto and Gonthier 2013).

Scots pine, like other plants, possesses defence mechanisms that provide protection against damage caused by biotic factors and environmental stresses. Constitutive tree defences deter pests and pathogen entry and invasion due to the presence of the physical barriers, e.g., lignified cell walls, waxy epidermal cuticle, and suberized bark as well as defensive chemicals (Franceschi et al. 2005). In contrast, inducible tree defences are activated in response to pathogen invasion, and include, among other factors, cell wall reinforcement, oxidative burst, and induction of certain biochemical pathways involved in the production of defensive chemicals, such as phenolics, terpenoids, and alkaloids (Kovalchuk et al. 2013). Certain chemical compounds may impart resistance to herbivorous insects and their associated pathogens (Keeling and Bohlmann 2006).

One of the common responses of conifer trees to fungal and insect attacks is an increased production of oleoresin, which is a complex mixture of volatile mono- and sesquiterpenes and diterpenoid resin acids (Napierala-Filipiak et al. 2002). Components of oleoresin display antifungal, antibacterial, or anti-insect properties. The composition of terpenoid compounds produced by individual trees show considerable variability within populations, allowing the recognition of so-called chemotypes. Chemotypes of Scots pine show remarkable differences in the proportions of produced monoterpenes, particularly $\alpha$-pinene and $\delta$-3-carene (Thoss et al. 2007; Bäck et al. 2012). Importance of terpenoid compounds in defense against pathogens and pests was previously demonstrated in numerous studies (Köpke et al. 2010; Ott et al. 2011; Roach et al. 2014). However, the contribution of individual terpenoid components may vary in different pathosystems. In Rocky Mountain lodgepole pine (Pinus contorta var. latifolia), terpene $\delta$-3-carene was found to be induced to higher level than $\beta$-pinene, which provided a greater level of defence against mountain pine beetles (Dendroctonus ponderosae) (Ott et al. 2011). In another study, $(+)-\alpha-$ pinene together with pinosylvin monomethyl ether were detected in the stems of Scots pine and were induced by the presence of the fungi Ophiostoma brunneo-ciliatum and Hyalorhinocladiella macrospora (Villari et al. 2012). In addition, an earlier finding revealed that the terpene concentration in Scots pine trees highly susceptible to H. annosum was significantly higher compared to less susceptible trees, while $\delta$-3-carene concentration was negatively correlated with lesion length in trees (Keriö 2015). Stilbene synthase also plays a role in the induced responses of Scots pine to fungal infection of $H$. annosum (Kovalchuk et al. 2017).

Plants including trees have immune defense mechanisms through sacrificing their infected cells for the benefit of the remaining cells, primarily aiming against infections caused by biotrophic pathogens (Jaber et al. 2014). Tree defense comprises two classes, namely resistance and tolerance. Resistance is the ability to reduce growth and infection of the pathogen, whereas tolerance is the ability to reduce or offset its negative performing such that trees can still grow and produce biomass and volume normally (Katjiua and Ward 2006; Sniezko and Koch 2017). In contrast to pathogenesis caused by necrotrophic pathogens, the mechanisms, usually known as hypersensitive response and programmed cell death (PCD), allow plants to prevent spread of biotrophic pathogens during an early stage of infection; however, hypersensitive response and PCD are not known to occur in necrotrophic root/butt diseases of forest trees (Han 2019). In contrast to previous studies, our study objective was to explore the possibility to identify tolerant trees based on their inherent genetic and chemical properties that are not dependent on chemicals or genes induced due to artificial inoculation.

We tested the hypothesis that the composition of terpenoid compounds in the needles of Scots pine trees can be used as a biochemical marker for predicting the level of tolerance to $H$. annosum infection. It was demonstrated previously that, despite pronounced differences in terpene content between needles and wood of Scots pine, the concentrations of many terpenoids in these tissues show a significant correlation (Manninen et al. 2002). This observation justifies our approach of testing concentrations of needle terpenoids as potential biochemical markers for tolerance against stem pathogen.

Furthermore, we assessed the expression level of selected genes involved in terpene, stilbene, and flavonoid biosynthesis and PCD in Scots pine trees with varying levels of tolerance to the pathogen. A primary motivation for the study was a need for the identification of reliable predictive markers that would allow estimation of tree tolerance to $H$. annosum infection in a non-invasive way, without performing artificial inoculations. Availability of such markers will greatly 
facilitate screening for trees with high tolerance to root disease, while decreasing the required cost and labor. Since we collected tree samples before inoculation for terpene compounds and gene expression analysis, we emphasize that this work is distinct from other studies (Zamponi et al. 2007; Madmony et al. 2018) where samples were collected post-inoculation. When trees are wounded, the production of secondary metabolic compounds is induced, which interferes with the identification of trees that are naturally genetically resistant. The primary objective is to explore the potential to identify markers for those tolerant trees that had inherent genetic make-up with constitutive gene expression that does not depend on pathogen induction.

\section{Materials and methods}

\section{Study site and sample collection}

The 10- to 15-year-old Scots pine (P. sylvestris L.) trees at a Research Forest site in Lapinjärvi (Uusimaa region, Southern Finland) were used in this study. The geographic position of the study site is $60^{\circ} 39^{\prime} 6^{\prime \prime} \mathrm{N}, 26^{\circ} 8^{\prime} 17^{\prime \prime} \mathrm{E}$ and its elevation is ca. $57 \mathrm{~m}$ above sea level. Collection of needle samples (second year) and artificial tree inoculation were performed on June 30, 2016. Before the inoculation of selected trees, needle samples were collected for RNA extraction and terpenoid analysis. These samples were kept on dry ice during sample harvesting and transportation, followed by storage at $-80{ }^{\circ} \mathrm{C}$ until used for analyses.

\section{Preparation of fungal inoculum}

The Scots pine wood dowels $(7 \mathrm{~mm}$ height, $10 \mathrm{~mm}$ diameter) colonized by $H$. annosum were used as the inoculum. The dowels were moistened with water $(20 \mathrm{ml} / 200$ dowels $)$ and autoclaved in glass jars for $20 \mathrm{~min}$. The sterile dowels were placed on $2 \%$ malt extract agar (MEA) plates to be precolonized by a heterokaryotic isolate of $H$. annosum (isolate 06068), followed by incubation for 3-4 weeks. Autoclaved dowels placed on sterile MEA plates were used as a control for mock inoculations.

\section{Inoculations, sample harvesting, and measurement}

The inoculation method used (Fig. 1) was similar as previously described (Keriö et al. 2014; Mukrimin et al. 2018). The stem surface was sterilized with $70 \%$ ethanol followed by making a hole with a $70 \%$ ethanol-sterilized puncher (10-mm diameter) through the tree bark to remove the rhytidome, phellem, and cambium. Inoculation spots were made at two spots on the stems of selected trees at $50 \mathrm{~cm}$ and $100 \mathrm{~cm}$ above ground level. The $H$. annosum-colonized dowels of the same diameter as the holes were placed in the holes and then covered with Parafilm $\mathbf{M}^{\circledR}$ (Sigma-Aldrich). For the control trees (mock inoculation), holes were filled with autoclaved wood dowels. The trees were harvested for phenotyping measurement 5 months post inoculation and stored at $-20{ }^{\circ} \mathrm{C}$ until used. There were 16 trees used for inoculation treatment and six trees for wounding or mock treatment.
Fig. 1 Illustration of inoculation and measurement method used in Scots Pine trees experiment in the field

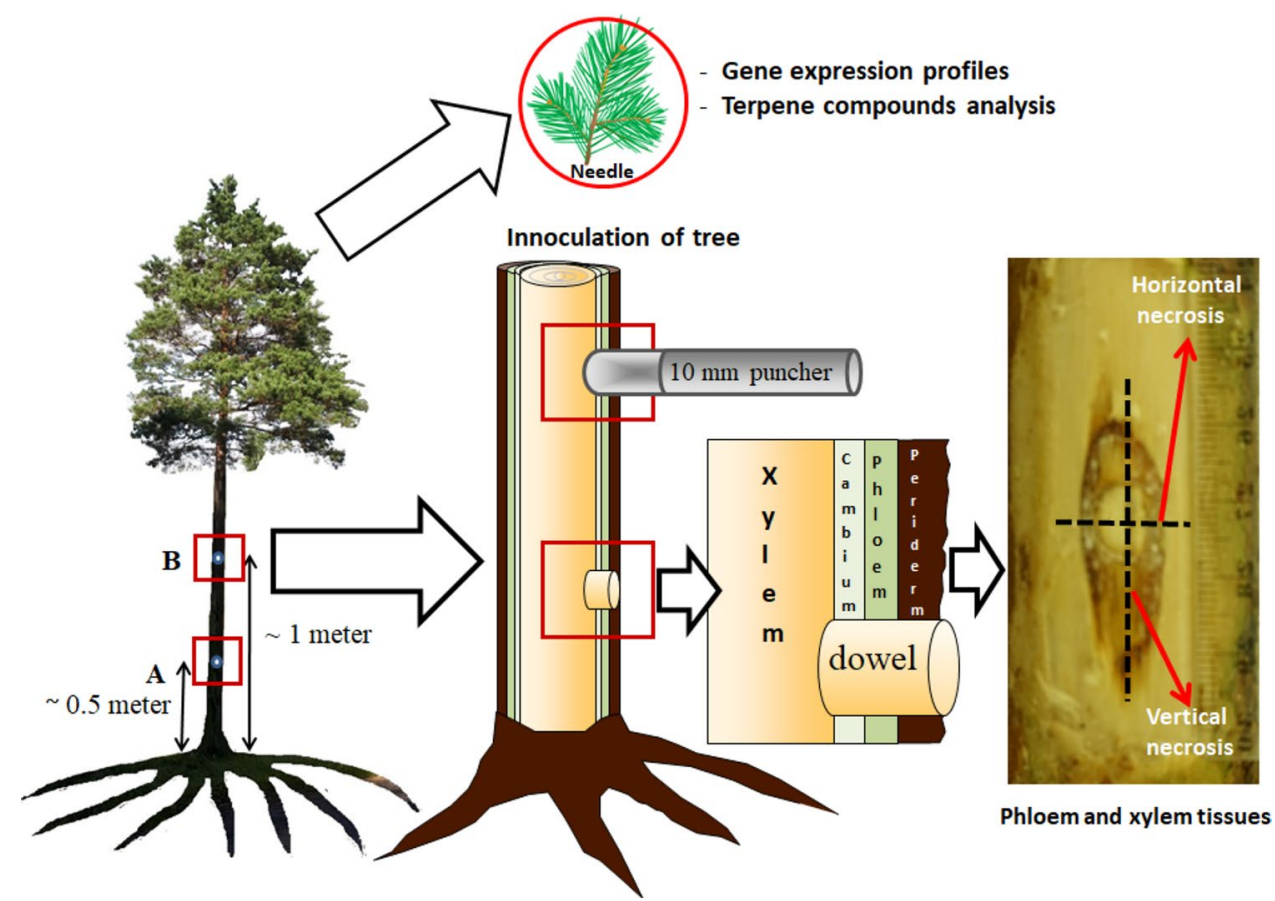


Table 1 List of primer sequences used for RT-PCR analysis in this study

\begin{tabular}{|c|c|c|c|c|c|}
\hline Primer & Primer sequence & $\begin{array}{l}\text { GenBank, ConGenIE and } \\
\text { PtNewbler1 accession } \\
\text { numbers }\end{array}$ & Predicted gene function & $\begin{array}{l}\text { Amplicon } \\
\text { length, bp }\end{array}$ & References \\
\hline $\begin{array}{l}\text { PsTPS5_F } \\
\text { PsTPS5_R }\end{array}$ & $\begin{array}{l}\text { gcttctactgcctgcgtctt } \\
\text { cgctgttcaggaattgaagg }\end{array}$ & GU248335.1 & Farnesene synthase & 64 & Köpke et al. (2010) \\
\hline $\begin{array}{l}\text { PcTPS_3Car1_F } \\
\text { PcTPS_3Car1_R }\end{array}$ & $\begin{array}{l}\text { tgtctcttatttccgctgtgc } \\
\text { tcacgaacagaactgatcaaaga }\end{array}$ & $\begin{array}{l}J Q 240307.1 \\
J Q 240305.1\end{array}$ & 3 -carene synthase 1 & 70 & Hall et al. (2013) \\
\hline $\begin{array}{l}\text { PbTPS_3Car2_F } \\
\text { PbTPS_3Car2_R }\end{array}$ & $\begin{array}{l}\text { tgtctgtggagatggtggaa } \\
\text { acgatgccgaatgaaggtta }\end{array}$ & JQ240306.1 & 3 -carene synthase 2 & 60 & Hall et al. (2013) \\
\hline $\begin{array}{l}\text { PbTPS_(+)apin_F } \\
\text { PbTPS_(+)apin_R }\end{array}$ & $\begin{array}{l}\text { gccgtctatgtaggccaaaac } \\
\text { aattcaacgggacagcaga }\end{array}$ & JQ240298.1 & $(+)-\alpha$-pinene synthase & 78 & Hall et al. (2013) \\
\hline $\begin{array}{l}\text { PcTPS_(-)apin_F } \\
\text { PcTPS_(-)apin_R }\end{array}$ & $\begin{array}{l}\text { ctgtgatctcgttgccttcc } \\
\text { gggttaagctcacgaccaga }\end{array}$ & JQ240303.1 & (-)- $\alpha$-pinene synthase & 73 & Hall et al. (2013) \\
\hline $\begin{array}{l}\text { isotig12807_F } \\
\text { isotig12807_R }\end{array}$ & $\begin{array}{l}\text { tcccgagaaaatacatgaatcc } \\
\text { agaacaggaggaacccgttt }\end{array}$ & isotig 12807 & $\begin{array}{l}\text { GPPS (geranyl diphosphate } \\
\text { synthase) }\end{array}$ & 69 & Keriö (2015) \\
\hline $\begin{array}{l}\text { isotig12811_F } \\
\text { isotig12811_R }\end{array}$ & $\begin{array}{l}\text { tttgattactgacaaggccactt } \\
\text { cccaacaactcgacagca }\end{array}$ & isotig 12811 & $\begin{array}{l}\text { GGPPS (geranylgeranyl } \\
\text { diphosphate synthase) }\end{array}$ & 78 & Keriö (2015) \\
\hline $\begin{array}{l}\text { isotig44391_F } \\
\text { isotig44391_R }\end{array}$ & $\begin{array}{l}\text { ctccccaaacaccttgtgat } \\
\text { gccttgtatggacaatgacg }\end{array}$ & isotig44391 & $\begin{array}{l}\text { GGPPS (geranylgeranyl } \\
\text { diphosphate synthase) }\end{array}$ & 64 & Keriö (2015) \\
\hline $\begin{array}{l}\text { isotig45191_F } \\
\text { isotig45191_R }\end{array}$ & $\begin{array}{l}\text { gcatcatccetgaccattg } \\
\text { tcctcatccaagcctttacg }\end{array}$ & isotig45191 & $\begin{array}{l}\text { GPPS (geranyl diphosphate } \\
\text { synthase) }\end{array}$ & 68 & Keriö (2015) \\
\hline $\begin{array}{l}17788-f \\
17788-r\end{array}$ & $\begin{array}{l}\text { gctctcagaatgtcgaaagca } \\
\text { gaaaccagacaccaatgttcc }\end{array}$ & isotig 17788 & Terpene synthase & 60 & Kovalchuk et al. (2015) \\
\hline $\begin{array}{l}13137-f .3 \\
13137-r .3\end{array}$ & $\begin{array}{l}\text { gttacttagacccgacagc } \\
\text { gcaacactgaagecatctc }\end{array}$ & isotig13137 & $\alpha$-pinene synthase & 108 & Keriö (2015) \\
\hline $\begin{array}{l}17929-f .2 \\
17929-r .2\end{array}$ & $\begin{array}{l}\text { ttcctgagcacgtcctc } \\
\text { tggtagcagcgegtatc }\end{array}$ & isotig 17929 & $\alpha$-pinene synthase & 97 & Keriö (2015) \\
\hline $\begin{array}{l}\text { PsTPS6_F } \\
\text { PsTPS6_R }\end{array}$ & $\begin{array}{l}\text { ttctgcagcaaatacattctcc } \\
\text { cgtcgatgagtctgattgtca }\end{array}$ & EF679330.1 & $\begin{array}{l}\text { caryophyllene/humulene } \\
\text { synthase }\end{array}$ & 69 & Köpke et al. (2008) \\
\hline $\begin{array}{l}\text { PsTPS7_F } \\
\text { PsTPS7_R }\end{array}$ & $\begin{array}{l}\text { tgggaatttctaaagcatgaca } \\
\text { tgcctcgtgcaagattga }\end{array}$ & EF679331.1 & $\begin{array}{l}\text { 1(10),5-germacradien-4-ol } \\
\text { synthase }\end{array}$ & 70 & Köpke et al. (2008) \\
\hline $\begin{array}{l}\text { STS_F } \\
\text { STS_R }\end{array}$ & $\begin{array}{l}\text { tccgactggaacaagttgttc } \\
\text { gcttggcctccaccegatcaag }\end{array}$ & X60753.1 & pinosylvin synthase & 73 & Kovalchuk et al. (2017) \\
\hline $\begin{array}{l}\text { CHS_F } \\
\text { CHS_R }\end{array}$ & $\begin{array}{l}\text { atggctgcaggaatgatgaagg } \\
\text { agtgccaatagcgaggatg }\end{array}$ & X60754.1 & chalcone synthase & 87 & Kovalchuk et al. (2017) \\
\hline $\begin{array}{l}\text { PaRNSI1-f } \\
\text { PaRNSI1-r }\end{array}$ & $\begin{array}{l}\text { ggacgctttcactgttatcgaatg } \\
\text { atcgttgtcccagaaaggagg }\end{array}$ & MA_95383g0020 & $\begin{array}{l}\text { RNSI1(ribonuclease } \\
\text { RNS1) }\end{array}$ & 88 & This study \\
\hline $\begin{array}{l}\text { PaRNSI2-f } \\
\text { PaRNSI2-r }\end{array}$ & $\begin{array}{l}\text { cagagcaacagttggtagattgcag } \\
\text { aaggcgttgtccataagccetc }\end{array}$ & MA_34759g0010 & $\begin{array}{l}\text { RNSI2 (ribonuclease } \\
\text { RNS1) }\end{array}$ & 70 & This study \\
\hline $\begin{array}{l}\text { PaCEP-f } \\
\text { PaCEP-r }\end{array}$ & $\begin{array}{l}\text { agaactcatggggtaccgactg } \\
\text { cgtttatagcgcacacaccataagg }\end{array}$ & MA_22695g0010 & $\begin{array}{l}\text { CEP (cysteine endopepti- } \\
\text { dase CEP) }\end{array}$ & 90 & This study \\
\hline $\begin{array}{l}\text { PaXCP-f } \\
\text { PaXCP-r }\end{array}$ & $\begin{array}{l}\text { atcgttagcttgccegagcag } \\
\text { aagtgccgtgcttctcccactc }\end{array}$ & MA_10433186g0010 & $\begin{array}{l}\text { XCP (xylem cysteine pepti- } \\
\text { dase XCP1) }\end{array}$ & 68 & This study \\
\hline $\begin{array}{l}\text { PaXBCP-f } \\
\text { PaXBCP-r }\end{array}$ & $\begin{array}{l}\text { gcagaggagaagcaacagag } \\
\text { ccaagccagtagctcaggttc }\end{array}$ & MA_10429635g0010 & $\begin{array}{l}\text { XBCP }(\text { xylem bark } \\
\text { cysteine peptidase } \\
\text { XBCP3) }\end{array}$ & 92 & This study \\
\hline $\begin{array}{l}\text { PaBFN-f } \\
\text { PaBFN-r }\end{array}$ & $\begin{array}{l}\text { ctgagtatgcagagggtgatcttg } \\
\text { caatgaagtgtaatggacttgaccag }\end{array}$ & MA_75204g0010 & BFN (endonuclease BFN1) & 93 & This study \\
\hline $\begin{array}{l}\text { PaMC5-f } \\
\text { PaMC5-r }\end{array}$ & $\begin{array}{l}\text { ggaagcccatcagcaacagg } \\
\text { gcagcatcggcgttattgtcac }\end{array}$ & MA_10430487g0010 & MC5 (metacaspase 5) & 112 & This study \\
\hline
\end{tabular}


Table 1 (continued)

\begin{tabular}{|c|c|c|c|c|c|}
\hline Primer & Primer sequence & $\begin{array}{l}\text { GenBank, ConGenIE and } \\
\text { PtNewbler } 1 \text { accession } \\
\text { numbers }\end{array}$ & Predicted gene function & $\begin{array}{l}\text { Amplicon } \\
\text { length, bp }\end{array}$ & References \\
\hline $37123-f$ & agttgactttccatccaacc & isotig 37123 & $\alpha-/ \beta$-pinene synthase & 84 & Keriö (2015) \\
\hline $37123-r$ & ctgtcctcctgataacatc & & & & \\
\hline $\begin{array}{l}\text { PsTPS3_F } \\
\text { PsTPS3_R }\end{array}$ & $\begin{array}{l}\text { gctgggaacgatacattgaag } \\
\text { caaacgtagggacatgtcgag }\end{array}$ & EF679332.1 & $\begin{array}{l}\text { longifolene/longipinene } \\
\text { synthase }\end{array}$ & 72 & Köpke et al. (2008) \\
\hline EF1-a_F & caccttgggagtgaagcaaatg & $E F 1-a$ & elongation factor $1 \alpha$ & 58 & Vestman et al. (2011) \\
\hline $\begin{array}{l}\text { EF1-a_R } \\
\text { isotig44517_F } \\
\text { isotig44517_R }\end{array}$ & $\begin{array}{l}\text { gggagtagtggcatccatcttg } \\
\text { gggagttggcatcatgagtt } \\
\text { gactttgaagacttcgctttcc }\end{array}$ & isotig44517 & Histone $\mathrm{H} 2 \mathrm{~A}$ & 66 & Keriö (2015) \\
\hline
\end{tabular}

\section{Phenotyping measurements and statistical analysis}

The necrotic lesions in phloem and xylem tissues were measured for both horizontal and vertical dimensions after removing the periderm tissues using a sterilized knife. The stem diameter was also documented. Based on phenotypic lesionsize data, trees were separated into two stringency levels (high and low) and further grouped as susceptible, moderate, or tolerant (Suppl. Table S1). Applying the low stringency level, tree samples having lesion size of $<120 \mathrm{~mm}$ were categorized as tolerant trees, lesion size of $120-180 \mathrm{~mm}$-as the intermediate trees, and the lesion size of $>180 \mathrm{~mm}$-as the susceptible. Using the high stringency level, tree samples having lesion size of $<106 \mathrm{~mm}$ were categorized as tolerant trees, lesion size of $106-240 \mathrm{~mm}$ - as the intermediate trees, and the lesion size of $>240 \mathrm{~mm}$ - as the susceptible. A one-way analysis of variance (ANOVA) was performed to detect differences among the necrotic lesion sizes between the inoculation and wounding treatments and between groups for gene expression level and terpene compounds. The growth rates of $H$. annosum were assessed by $t$ tests for two-sample assuming unequal variances. Pearson's correlation analysis was used to determine correlations between the stem diameter and the sizes of necrotic lesions (sum of all necrosis, horizontal and vertical lesions for both phloem and xylem). Differences were considered as statistically significant if $P$ value was below the threshold of 0.05. Phenotyping data were analyzed using the SPSS version 25.0 (IBM Corporation).

\section{RNA extraction, CDNA preparation, and RT-PCR analysis}

RNA was extracted from the Scots pine needles as described previously (Chang et al. 1993) with some modification. In brief, Scots pine's needles were grounded using an IKA ${ }^{\circledR}$ A11 basic mill (IKA-Werke, Staufen, Germany). The sample $(2 \mathrm{~g})$ was transferred to a $50 \mathrm{ml}$ sterile tube and resuspended in $10 \mathrm{ml}$ extraction buffer (2\% CTAB, $2 \%$ PVP,
$100 \mathrm{mM}$ Tris-HCl, $25 \mathrm{mM}$ EDTA, $2 \mathrm{M} \mathrm{NaCl}$, and nucleasefree water) and $200 \mu \mathrm{l}$ of mercaptoethanol (pre-warmed at $65^{\circ} \mathrm{C}$ ). After vortexing, the mixture was incubated for $6 \mathrm{~min}$ at $65{ }^{\circ} \mathrm{C} .10 \mathrm{ml}$ of chloroform-isoamyl alcohol $(24: 1, \mathrm{v} / \mathrm{v})$ was added and mixed and centrifuged at $10,000 \mathrm{~g}$ at $24^{\circ} \mathrm{C}$. $9 \mathrm{ml}$ of supernatant and an equal volume of chloroformisoamyl alcohol $(24: 1, \mathrm{v} / \mathrm{v})$ were transferred to a new $50 \mathrm{ml}$ sterile tube. After centrifugation at $10,000 \mathrm{~g}$ for $10 \mathrm{~min}$ at $24{ }^{\circ} \mathrm{C}, 8 \mathrm{ml}$ of supernatant was transferred to a new $50 \mathrm{ml}$ sterile tube and added with $2 \mathrm{ml}$ of $10 \mathrm{M} \mathrm{LiCl}$, followed by precipitation at $4{ }^{\circ} \mathrm{C}$ overnight. The solution was centrifuged at $10,000 \mathrm{~g}$ for $30 \mathrm{~min}$ at $4{ }^{\circ} \mathrm{C}$ and the supernatant was pipetted out carefully. After drying, $200 \mu \mathrm{l}$ of cold $70 \%$ ethanol was added to the pellet and then centrifuged at $10,000 \mathrm{~g}$ for 5 min at $4{ }^{\circ} \mathrm{C}$. The supernatant was then pipetted out and the pellet was dried out. The pellet was suspended in $100 \mu \mathrm{l}$ of nuclease-free water and RNA samples were stored at $-80^{\circ} \mathrm{C}$.

Each RNA sample $(1 \mu \mathrm{g})$ was treated with DNase I (Thermo Scientific), and cDNA was synthesized by RevertAid Reverse Transcriptase (RT) (Thermo Scientific) according to the manufacturer's instructions. In this study, 25 primer pairs were used (Lorenz et al. 2012; Nystedt et al. 2013; Keriö 2015; Sundell et al. 2015) (Table 1).

qPCR reactions were carried out using the LightCycler 480 II instrument (Roche). Two technical replicates were carried out and each reaction was performed as follows: $5.5 \mu \mathrm{l}(11 \mathrm{ng}$ ) of cDNA, $1 \mu \mathrm{l}$ forward primer (final concentration $0.67 \mu \mathrm{M}$ ), $1 \mu 1$ reverse primer (final concentration $0.67 \mu \mathrm{M}$ ) and $7.5 \mu \mathrm{l}$ Master-Mix (Roche). The following cycling parameters were applied: initial pre-incubation at $95^{\circ} \mathrm{C}$ for 5 min followed by 45 amplification cycles $(10 \mathrm{~s}$ at $95^{\circ} \mathrm{C}, 10 \mathrm{~s}$ at $55^{\circ} \mathrm{C}$ and $10 \mathrm{~s}$ at $72{ }^{\circ} \mathrm{C}$ ). A final melting curve analysis was also included to assess the primer specificity. The crossing points $(\mathrm{Cp})$ values were calculated with the second derivative method using the Roche LightCycler 480 software (version 1.5.1.62). Primer efficiencies were applied in the calculation of the relative expression level of each gene with the $2^{-\Delta \Delta C T}$ method (Livak and Schmittgen 2001) 


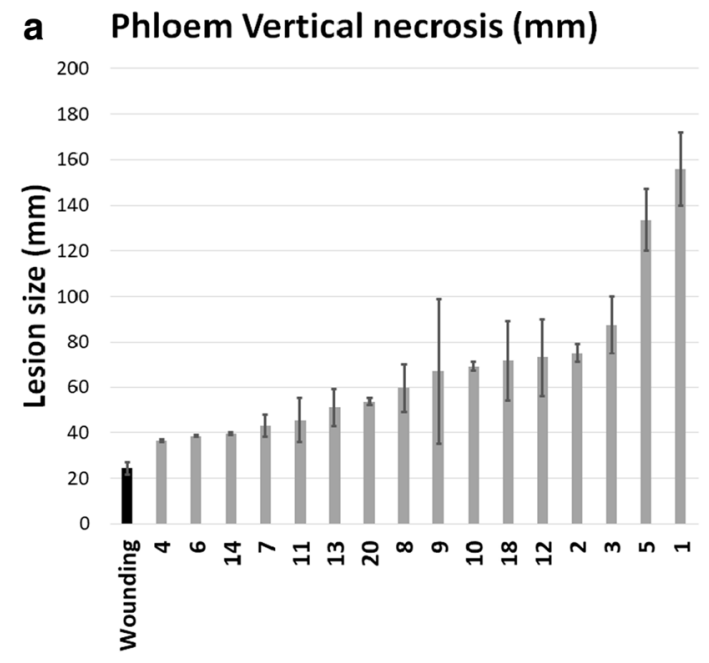

Plant ID

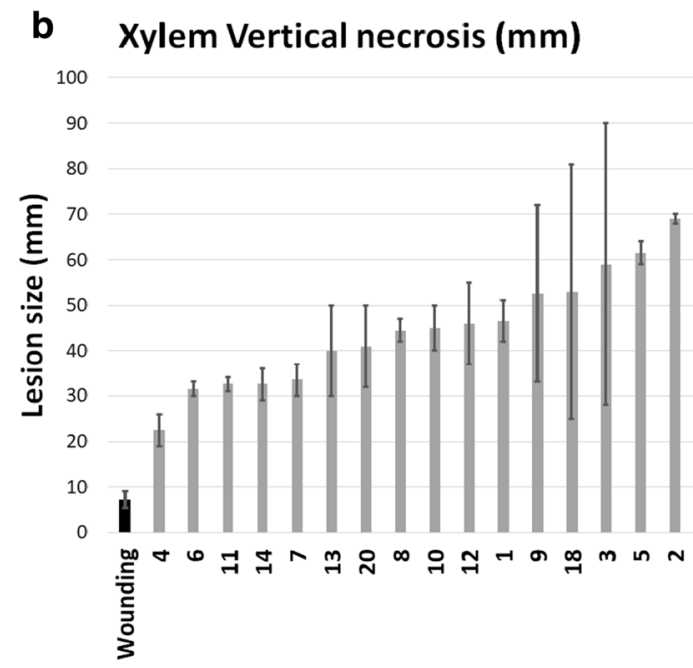

Plant ID

C $_{300}$ sum of all lesions $(\mathrm{mm})$

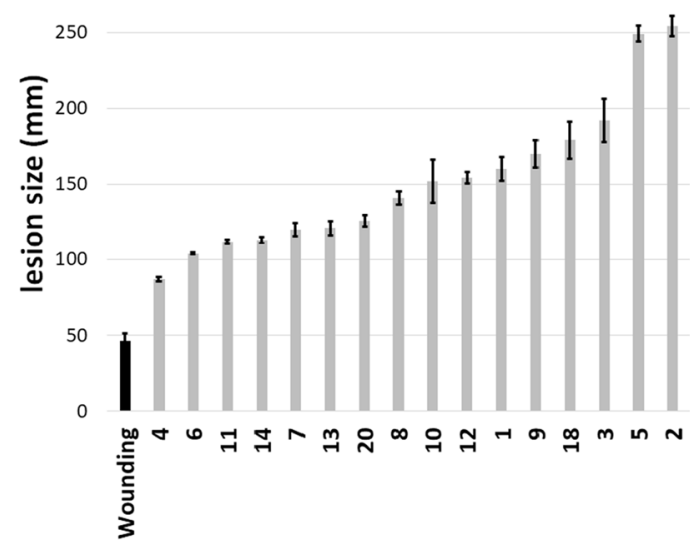

Plant ID
Necrosis of Scots Pine's phloem

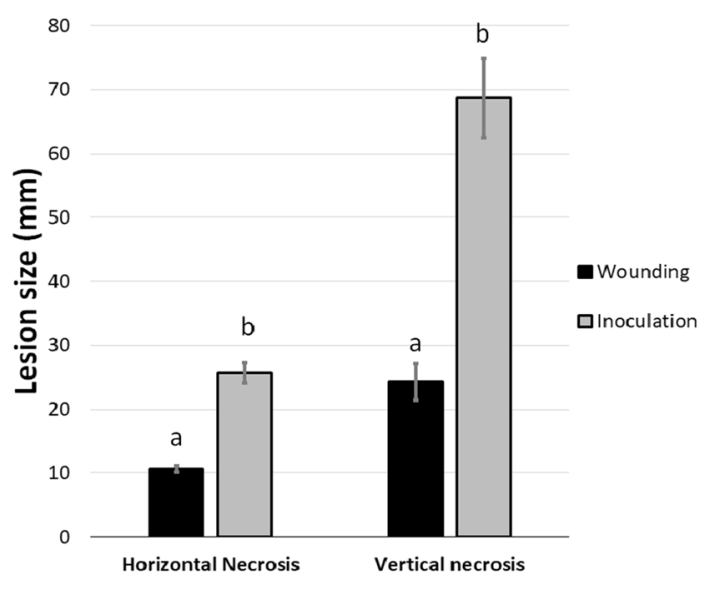

Necrosis of Scots Pine's Xylem

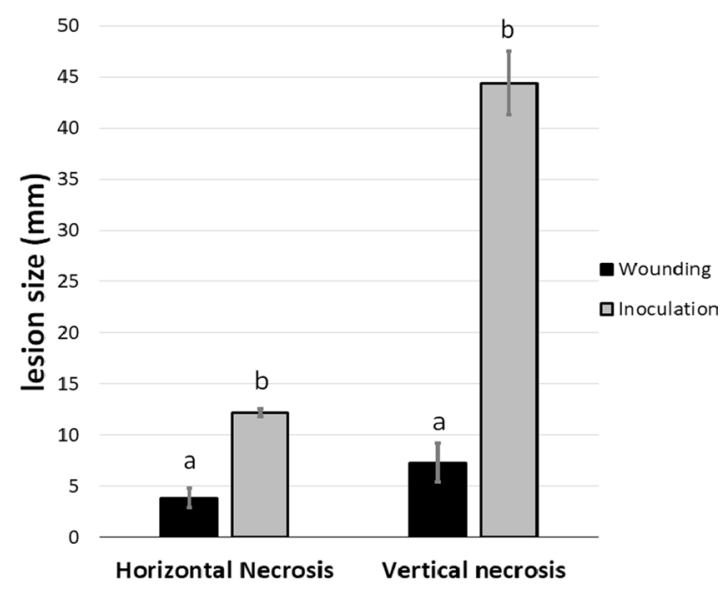

sum of all lesions

200

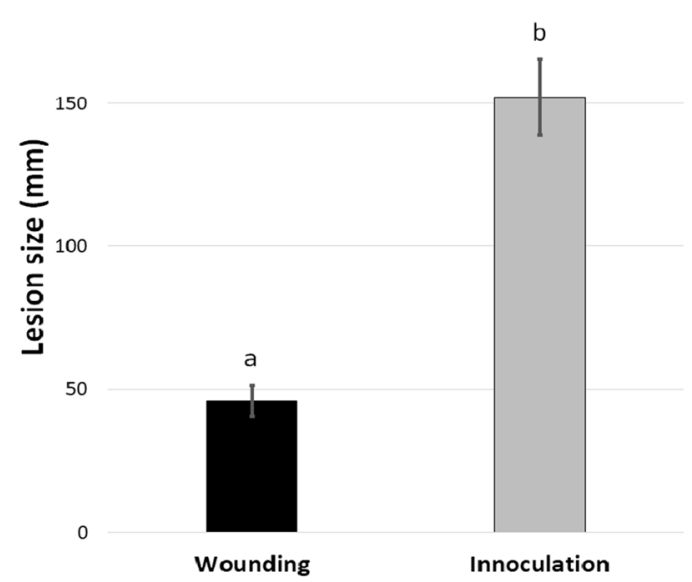


४Fig. 2 Mean of measurement result of a phloem vertical necrosis, b xylem vertical necrosis, $\mathbf{c}$ sum of all lesions for wounded and inoculated trees showing significant difference at $P<0.005$. The error bar is reflected as SE

to estimate the relative expression values of the genes in the sampled trees. The genes encoding elongation factor 1 alpha (EF-1 $\alpha$ ) (Vestman et al. 2011) and histone H2A (Keriö 2015) were used as reference genes, but histone $\mathrm{H} 2 \mathrm{~A}$ had low expression level and was excluded from the analysis. The crossing points ( $\mathrm{Cp}$ ) values from the RT-PCR were imported and analyzed in SPSS Statistics 25 software (IBM).

\section{Terpenoids analyses}

Terpenoids were analyzed from needle samples of Scots pine using previously published methods (Kainulainen et al. 1992). Needle samples were cut into small pieces under $\mathrm{N}_{2}$ and $200 \mathrm{mg}$ of samples were extracted in $2 \mathrm{ml}$ of $n$-hexane at room temperature for $2 \mathrm{~h}$ and washed twice with $2 \mathrm{ml} n$-hexane. 1-chloro-octane was used as an internal standard. The extracts were analyzed using an Agilent 7890B gas chromatograph equipped with a mass-selective detector (type 5977A). Separations were carried out on a 30-m HP-5 ms Ultra Inert (i.d. $0.25 \mathrm{~mm}$; film thickness $0.25 \mu \mathrm{m}$, Agilent) column. Helium was used as carrier gas, and linear velocity was about $40 \mathrm{~cm} / \mathrm{s}$. The splitless (purge time off $1 \mathrm{~min}$ ) sampling technique was used, and $1 \mu \mathrm{l}$ was injected. The column temperature was programmed from 50 to $115^{\circ} \mathrm{C}$ at $5^{\circ} \mathrm{C} / \mathrm{min}$, then to $280{ }^{\circ} \mathrm{C}$ at $15^{\circ} \mathrm{C} / \mathrm{min}$ and hold for $10 \mathrm{~min}$. Mass numbers from $\mathrm{m} / \mathrm{z} 33$ to 350 were recorded. Compound identification and quantification were based on their mass spectra, retention time, and authentic standard compounds as described by Kainulainen et al. (1992). Limonene and $\beta$-phellandrene were coeluted.

Principal coordinates analysis (PCoA) was used to visualize the structure of the tolerant, intermediate, and susceptible trees based on the xylem vertical necrosis. Distance-based linear model (DistLM) analyses were performed to assess the correlation of the susceptible, intermediate, and tolerant trees with gene expression profiles and with monoterpene and sesquiterpene concentrations as variables in PRIMER v.6 (Clarke and Gorley 2006) with the add-on package of Permutational Multivariate Analysis of Variance (PERMANOVA)+ (Anderson et al. 2008).

\section{Results}

\section{Variation in lesion length in response to $H$. annosum inoculation}

At 5 months post infection, the vertical length of necrotic lesions in the inoculated Scots pine stems varied from
36.5 to $156 \mathrm{~mm}(68.7 \pm 9.4 \mathrm{~mm})$ and from 22.5 to $69 \mathrm{~mm}$ $(44.4 \pm 8.5 \mathrm{~mm})$ in phloem and xylem, respectively. The total necrotic lesion size, based on sum of all lesions (phloem and xylem), varied from 87 to $254 \mathrm{~mm}(152.13 \pm 12.07 \mathrm{~mm})$. The lesion length was significantly larger in inoculated than in wounded trees $(P<0.001)$ for phloem vertical necrosis, xylem vertical necrosis, and sum of all lesions (Fig. 2).

The lesion length was normally distributed among the analyzed trees; hence, the inoculation treatment was classified into three groups according to the sum of all necrosis, namely tolerant, intermediate, and susceptible trees (Suppl. Fig. S1). Lesion sizes were significantly different $(P<0.001)$ among the groups and between inoculation and wounding. Based on Pearson's analysis, the tree diameter (growth trait) was significantly positively correlated with length of necrotic lesions in phloem (Table 2 and Fig. 3). In contrast, tree diameter showed a significant negative correlation with wounding horizontal necrosis in phloem (Table 2). In addition, xylem vertical necrosis showed a significant positive correlation with phloem horizontal, phloem vertical, xylem horizontal necrosis, and sum of all necrosis (Fig. 3).

\section{Gene expression analysis}

The relative gene expression is presented in Fig. 4a. We found that significant differences were evident among groups (tolerant, intermediate, and susceptible) in genes encoding $\alpha$-pinene synthase for the sum of all necrosis measurements $(P=0.012)$, and $(-)-\alpha$ pinene synthase for xylem vertical necrosis $(P=0.027)$ (Suppl. Table S2). While for genes encoding geranyl diphosphate synthase (GPPS) and metacaspase 5 (MC5), no significant differences were observed among the groups $(P>0.05)$.

The results of correlation analysis are presented in Table 3 and Fig. 5. The expression level of a gene encoding predicted $\alpha$-pinene synthase showed a positive correlation with the sum of all necrosis measurements (Fig. 5a). Correlation results for a putative (-)-alpha pinene synthase, a predicted GPPS, and MC5 are displayed in Fig. 5b-d and Suppl. Fig. S2. Trees with larger necrotic lesions were characterized by moderately increased transcript level of these three genes. Pearson's anal$y$ sis showed that expression levels of a predicted $\alpha$-pinene synthase gene had a positive correlation with the sum of all necrosis. Both a putative (-)-alpha pinene synthase gene and a predicted GPPS gene had a positive correlation with the size of xylem vertical necrosis, whereas the expression level of MC5 homologue had a positive correlation with the size of phloem horizontal necrosis (Table 3 ).

\section{Terpene profiles of Scots pine needles}

Results of analyses of terpenoid compounds in pine needles are presented in the Fig. $4 \mathrm{~b}$, c. The monoterpenes with 
Table 2 Correlation coefficients between diameter and lesion size based on Pearson's analysis ( $n=16$ for inoculated trees and $n=6$ for mock trees)

\begin{tabular}{lc}
\hline & Diameter \\
\hline Inoculation & \\
Phloem horizontal necrosis & -0.101 \\
Phloem vertical necrosis & $0.530^{* *}$ \\
Xylem horizontal necrosis & -0.149 \\
Xylem vertical necrosis & 0.156 \\
Mock inoculation & \\
Phloem horizontal necrosis & $-0.542^{*}$ \\
Phloem vertical necrosis & 0.028 \\
Xylem horizontal necrosis & -0.194 \\
Xylem vertical necrosis & -0.242 \\
\hline
\end{tabular}

Significant correlation at $* P<0.05$ and $* * P<0.01$

the highest concentrations were $\alpha$-pinene and $\delta$-3-carene (mean $>1000 \mu \mathrm{g} / \mathrm{g} \mathrm{FW}$ ), the concentrations of remaining compounds were less than $250 \mu \mathrm{g} / \mathrm{g} \mathrm{FW}$. In the tolerant trees, $\alpha$-pinene, limonene $+\beta$-phellandrene (co-eluted), trans- $\beta$ ocimene, and $\beta$-pinene had higher concentration compared with other monoterpenes. Whereas, the highest concentration of monoterpenes in susceptible trees were $\delta$-3-carene, bornyl acetate, tricyclene, sabinene, and $\alpha$-thujene.

Among the analyzed sesquiterpenes, $\alpha$-muurolene and $\beta$-elemene had the highest concentrations ( $>250 \mu \mathrm{g} / \mathrm{g} \mathrm{FW}$ ). In the tolerant trees, g-elemene had a higher concentration, compared with other sesquiterpenes. None of the analyzed mono- and sesquiterpenes compounds had significant difference among the groups $(P>0.05)$ (Suppl. Table S2).

Each lesion-length group varied in their total terpene concentration. We found that $\beta$-caryophyllene showed a negative correlation with sizes of phloem horizontal and vertical necrosis, and sum of all necrosis measurements; whereas $\alpha$-humulene had negative correlation with the size of phloem vertical necrosis (Fig. 5e-h and Suppl. Fig. S3). Additionally, we found no significant differences among tolerant, intermediate, and susceptible trees in the total concentration of sesquiterpenes or monoterpenes $(P>0.05)$ (Suppl. Fig. S4).

PCoA and PERMANOVA analysis showed a clear separation between tolerant and susceptible trees (Fig. 6). We assessed a possible correlation of different factors (gene expression, mono- and sesquiterpenes) with the lesion size.

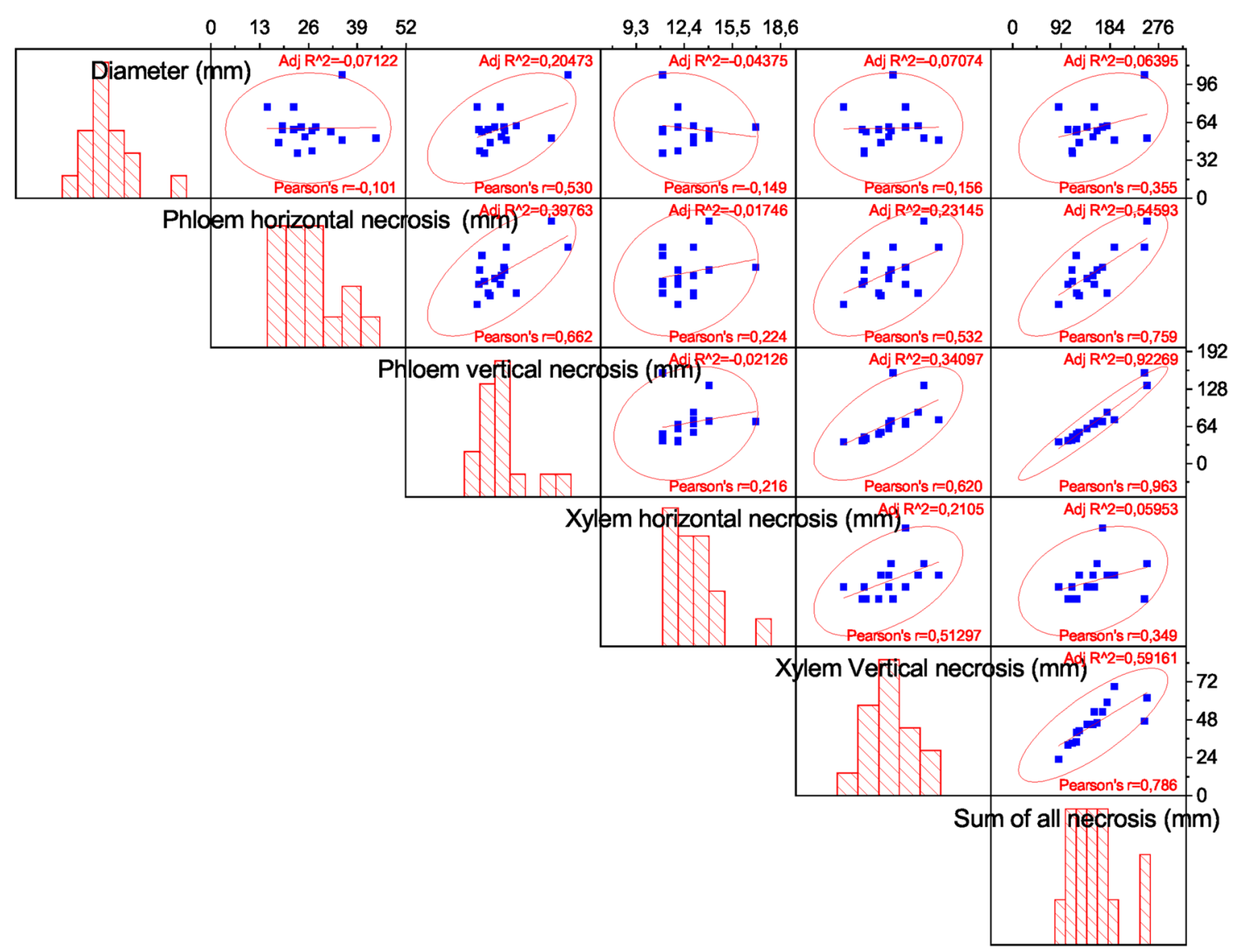

Fig. 3 Scatterplot matrix of correlation between diameter and phloem horizontal, phloem vertical, xylem horizontal, and xylem vertical necrosis 

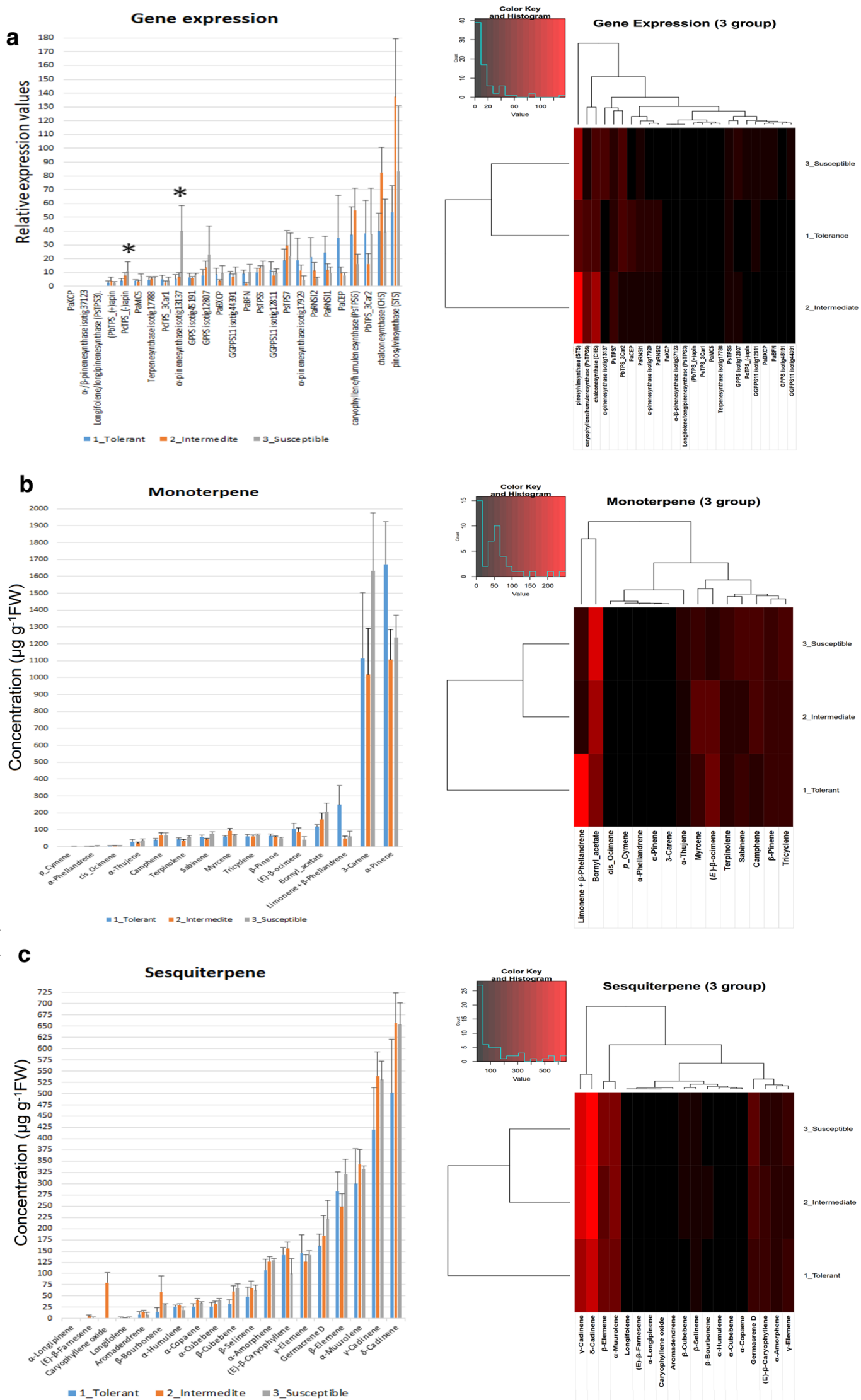

Fig. 4 Mean and heatmap for three group of trees based on sum of all necrosis. a Gene expression profiles. b Monoterpene compounds. c Sesquiterpene compounds 
Table 3 Pearson correlation coefficients for gene expression and necrosis and for Sesquiterpenes and necrosis

Sum of all necrosis (mm)

\begin{tabular}{|c|c|c|}
\hline \multicolumn{3}{|l|}{ Based on the sum of all necrosis } \\
\hline \multicolumn{3}{|l|}{ Gene expression } \\
\hline$\alpha$-pinenesynthase (isotig13137) & & $0.528^{*}$ \\
\hline \multicolumn{3}{|l|}{ Sesquiterpene $(\mu \mathrm{g} / \mathrm{gFW})$} \\
\hline \multirow[t]{2}{*}{$\beta$-Caryophyllene } & & $-0.511^{*}$ \\
\hline & Phloem horizontal necrosis (mm) & Xylem vertical necrosis (mm) \\
\hline \multicolumn{3}{|l|}{ Based on phloem and xylem necrosis } \\
\hline \multicolumn{3}{|l|}{ Gene expression } \\
\hline (-)- $\alpha$ pinene synthase (PcTPS_(-)apin) & 0.088 & $0.529^{*}$ \\
\hline GPPS (isotig12807) & 0.068 & $0.549^{*}$ \\
\hline MC5 & $0.586^{*}$ & 0.238 \\
\hline \multicolumn{3}{|l|}{ Sesquiterpenes $(\mu \mathrm{g} / \mathrm{gFW})$} \\
\hline$\beta$-Caryophyllene & $-0.513 *$ & $-0.553^{*}$ \\
\hline$\alpha$-Humulene & -0.480 & $-0.518^{*}$ \\
\hline
\end{tabular}

Significant correlation at $* P<0.05$ and $* * P<0.01$

Among selected genes, only the gene encoding predicted $\alpha$-pinene synthase (isotig13137) had a nearly significant expression level $(P=0.056)$. None of analyzed monoterpenes showed significant correlation with the lesion size. Among sesquiterpenes, $\beta$-caryophyllene was significantly correlated with lesion size $(P=0.05)$, whereas $\alpha$-humulene was nearly significant $(P=0.068)$ (Suppl. Table S3).

\section{Discussion}

Despite the fact that field studies on root disease in natural forest ecosystem require more time than greenhouse studies (Swedjemark and Stenlid 1996), artificial inoculations have been applied successfully in the field experiments to examine tree susceptibility to Heterobasidion infection (Swedjemark and Karlsson 2004; Karlsson et al. 2008; Danielsson et al. 2011; Keriö et al. 2014). Although artificial inoculation followed by sampling of lesion areas is commonly done, relying solely on destructive inoculation to screen for resistant genotypes poses a technical and logistical challenge, which may be impractical for large-scale screening of novel biomarkers for durable resistance. One notable challenge is that chemicals induced due to destructive inoculation may be localized within the necrotic lesions. In this study, an alternative approach was explored. Samples for terpenoid and gene expression were collected prior to destructive inoculation. The results were later compared against necrotic lesions and used to identify genotypes that might be inherently tolerant or susceptible. Necrotic lesion size was used as a measure of host susceptibility or tolerance, while inoculation and mock treatments were used for comparing differential responses of Scots pine trees to $H$. annosum infection.

The findings revealed that each individual Scots pine host genotype displayed a different degree of susceptibility to $H$. annosum. We found a significantly higher lesion size in inoculated treatments compared to mock inoculations, which is in accordance with a previously published work (Danielsson et al. 2011). Our study indicates that Scots pine trees with higher values of growth (diameter) showed considerably more sensitivity to $H$. annosum infection, particularly in phloem vertical necrosis. This result concurs with a previous result (Swedjemark and Karlsson 2004), which clearly described that lesion length and fungal growth were positively correlated to diameter (growth trait) of $P$. abies. In contrast, (Karlsson et al. 2008) showed that stem diameter of $P$. abies had a strong negative correlation to both lesion size and fungal extension of $H$. parviporum. Another study revealed the diameter of Norway spruce saplings was significantly negatively correlated with lesion length particularly in xylem (Mukrimin et al. 2018).

Terpenoids are one of the largest group of defensive chemicals occurring in conifers (also found in broad-leaved trees), and this group is the most abundant compound class involved in chemical defense (Huber and Bohlmann 2006). Besides that, terpenoids are promising biochemical markers for characterizing of diverse tree species and for estimating geographic variation among different origins of $P$. abies (Persson et al. 1996). Composition of terpenoid compounds varies between different tissues (e.g., needles and wood) of the same tree. However, both proportional and absolute concentrations of individual compounds in needles and wood of Scots pine show significant correlations (Manninen 

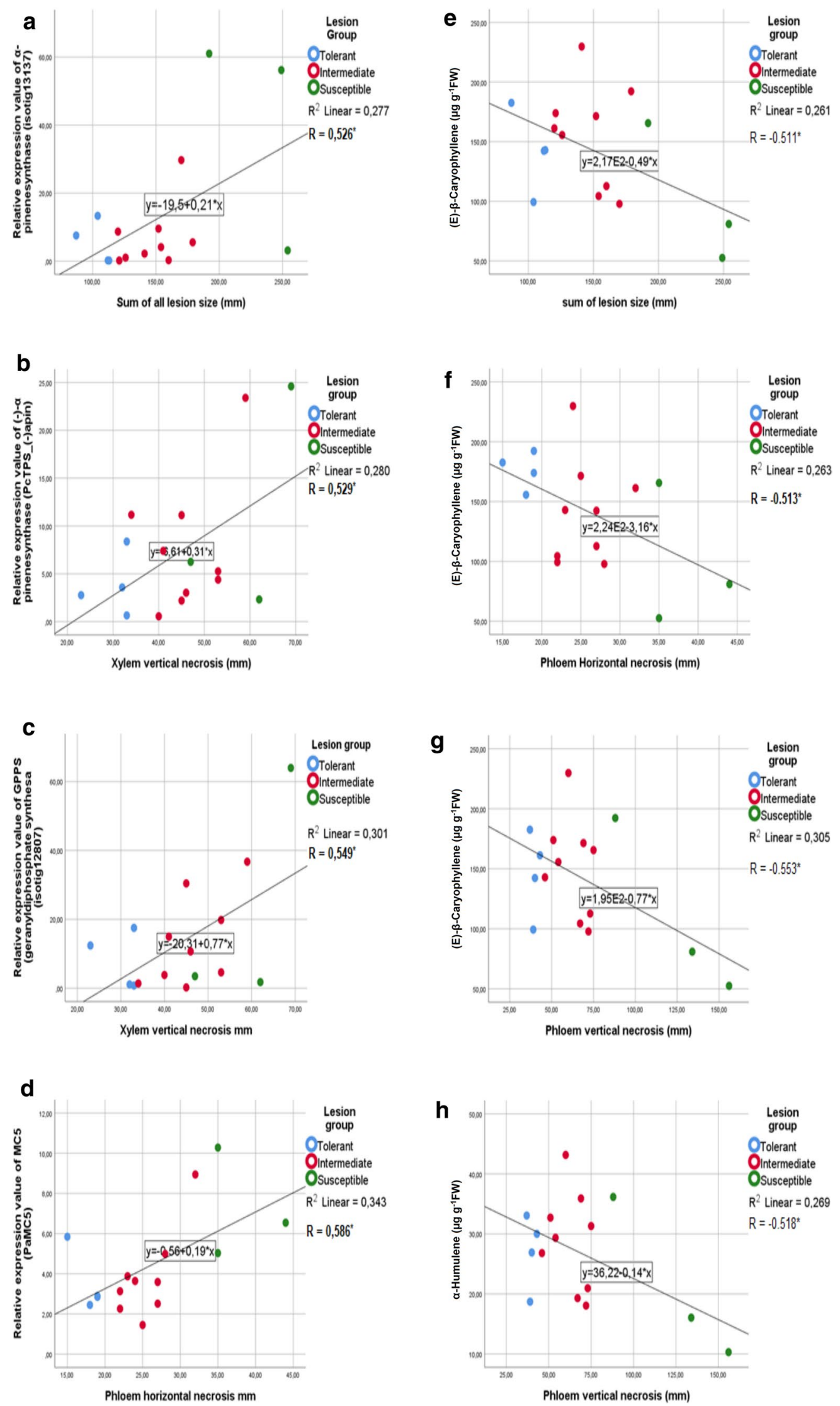

Fig. 5 Scatterplot of gene expression profiles and sesquiterpene compounds based on both sum of all necrosis and phloem and xylem necrosis 

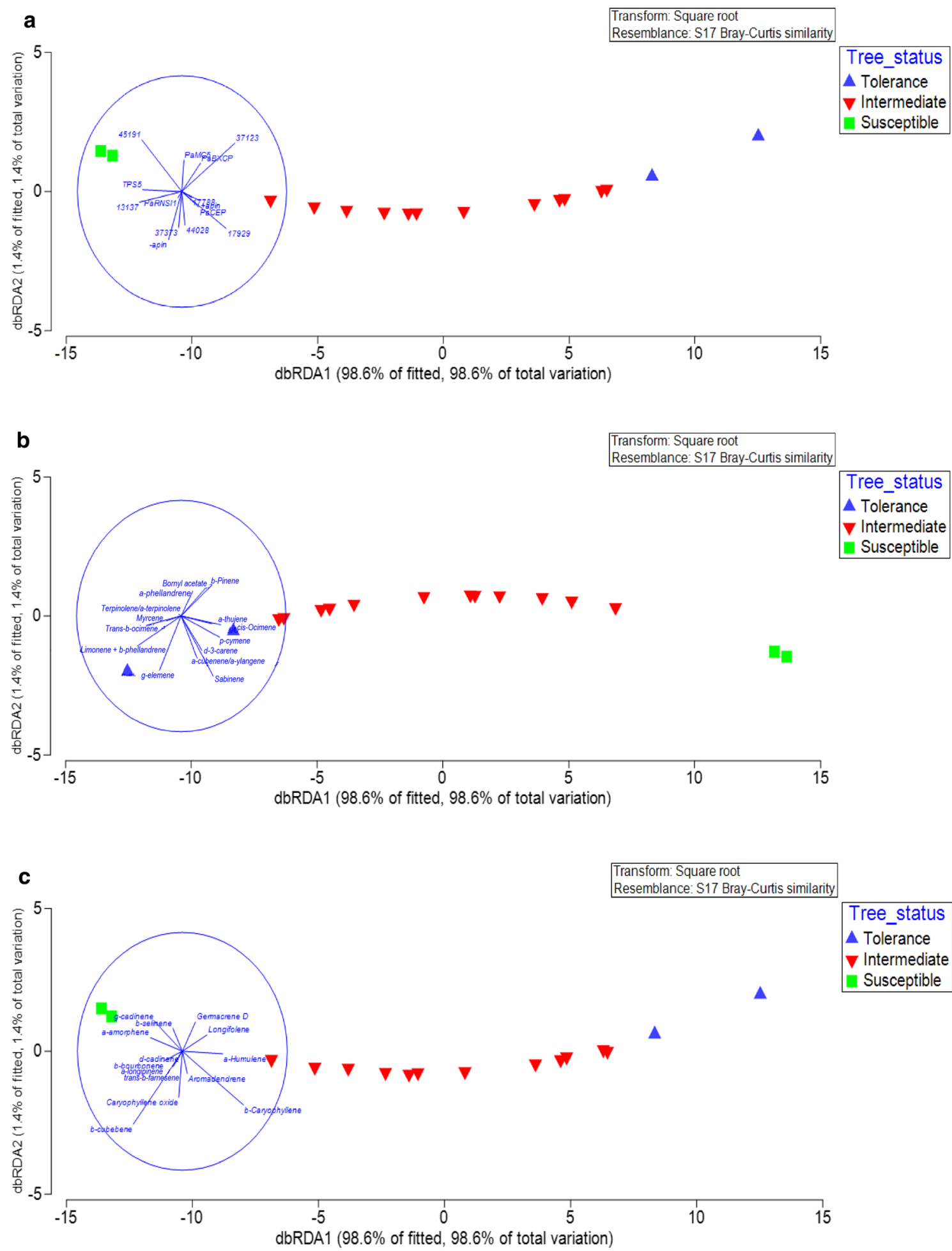

Fig. 6 Principal coordinates analysis (PCoA) based on the gene expression and terpene chemical compound relating to sum of all necrosis for samples from tolerance, intermediate, and susceptible

et al. 2002), supporting the idea of using needle terpene profiles as biochemical markers for resistance against stem pathogens. Our data demonstrated that the concentrations of trees indicated with different symbols and colours. a Gene expression as factor. b Monoterpene as factor. c Sesquiterpene as factor

$\beta$-caryophyllene and $\alpha$-humulene in Scots pine needles show significant negative correlation with the size of necrotic lesions developing in phloem in response to the inoculation 
with $H$. annosum. Trees with lower concentrations of these two compounds were characterized by the largest necrotic lesions. At the same time, only two out of 36 assayed terpenoids showed correlation with the necrotic lesion size. This is in line with earlier reports showing lack of clear correlation between terpenoid content and resistance to wood-decay fungi (Nerg et al. 2004).

The high concentrations of terpene compounds recorded in the current study were similar to an earlier study. This study showed that $\delta$-3-carene and $\alpha$-pinene were the most abundant monoterpenes in Scots pine, which is supported by previous studies in which $\delta$-3-carene and $\alpha$-pinene were reported to be the most abundant monoterpenes in Scots pine (Vanhatalo et al. 2018) and white bark pine (Bullington et al. 2018). Other authors (Baradat and Yasdani 1988) revealed that Scots pine trees exhibited a strong broad-sense heritability of 3-carene, myrcene, limonene, and $\beta$-phellandrene under different environmental condition. Muona et al. (1986) found differences in 3-carene and other monoterpene compounds between natural stands and plus trees of Scots pine. Another previous study also found that the only detected sesquiterpene on the Scots pine seedling was $\beta$-caryophyllene (Tiiva et al. 2018). Whereas, the $\beta$-caryophyllene was the most abundant terpene of wood resin in maritime pine trees, either attacked or un-attacked by Dioryctria sylvestrella (Jactel et al. 1996). Another finding showed that Scots pine trees have increased release of terpenoids ( $\beta$-caryophyllene and $\alpha$-humulene) when pine common sawfly (Diprion pini) laid eggs on Scots pine needles (Köpke et al. 2010). These compounds ( $\beta$-caryophyllene and $\alpha$-humulene) have been shown to attract a biocontrol agent (Closterocerus ruforum) that parasitizes the sawfly eggs and plays a role in direct defense against sawfly larvae (Köpke et al. 2010).

The groups of tolerant and highly susceptible trees could not be reliably separated based on the expression pattern of the tested genes, despite some observed correlations of gene expression levels with the size of necrotic lesions. Within the sampled population, we observed considerable variation in the expression of many of the selected genes, which could be partly due to the genotypic differences of individual trees. Larger sample sizes may help identify statistically significant associations of expression level of certain genes with the degree of tolerance of Scots pine to $H$. annosum infection.

Despite studies of conifer defenses that showed $\delta$-3carene synthase expression has significant correlation to resistant trees (e.g., Fäldt et al. 2003; Roach et al. 2014), we found no support for this relationship in our study. Thus, the specific role of $\delta-3$-carene synthase in the tree defense is still not well understood. It is also remains possible that increased levels of $\delta$-3-carene or $\delta$-3-carene synthase expression documented in lesion areas do not correlate to systemic or inherent abundance, or that chemotypic variation (e.g., $\alpha$-pinene and $\delta$-3-carene types) in Scots pine may mask other changes.

Our study identified four genes ( $\alpha$-pinene synthase (two genes), GPPS, and MC5) and two sesquiterpene compounds ( $\beta$-caryophyllene, and $\alpha$-humulene) suitable for further exploration as potential markers of tolerance/susceptibility of Scots pine trees to $H$. annosum infection. These data can provide additional support for future research on tree resistance to root and butt rot diseases. The role of the identified genes and compounds in the defense of pine trees deserves further investigation.

Author contribution statement Phenotyping of Scots pine trees was done by MM and AK; RNA extraction, cDNA analysis, and qPCR analysis were performed by MM and AK; terpenoid analysis was carried out by RJ, MK, and JH; $\mathrm{MM}$ and $\mathrm{AK}$ analyzed the data; MM and AK prepared the manuscript draft; MM, AK, and FA conceived the study, contributed to the experimental design and interpretation of the data. All authors read and approved the final version of the manuscript.

Acknowledgements Open access funding provided by University of Helsinki including Helsinki University Central Hospital. This study was supported by funding from the Academy of Finland (No. 278424 to JKH; No. 307580 to FOA) and the Doctoral Programme in Plant Sciences (DPPS) at the University of Helsinki, Finland. The Ministry of Research, Technology, and Higher Education (RISTEKDIKTI) of the Republic of Indonesia is acknowledged for the financial support for doctoral project of MM. We thank Dr. Risto Kasanen for help in field sampling.

\section{Compliance with ethical standards}

Conflict of interest Authors declare no conflicts of interest.

Open Access This article is distributed under the terms of the Creative Commons Attribution 4.0 International License (http://creativeco mmons.org/licenses/by/4.0/), which permits unrestricted use, distribution, and reproduction in any medium, provided you give appropriate credit to the original author(s) and the source, provide a link to the Creative Commons license, and indicate if changes were made.

\section{References}

Anderson M, Gorley RN, Clarke KR (2008) PERMANOVA+ for PRIMER: guide to software and statistical methods. Prim Ltd. https://doi.org/10.1016/j.isatra.2014.07.008

Asiegbu FO, Adomas A, Stenlid J (2005) Conifer root and butt rot caused by Heterobasidion annosum (Fr.) Bref. s.1. Mol Plant Pathol 6:395-409. https://doi.org/10.1111/j.1364-3703.2005.00295.x

Bäck J, Aalto J, Henriksson M et al (2012) Chemodiversity of a Scots pine stand and implications for terpene air concentrations. Biogeosciences 9:689-702. https://doi.org/10.5194/bg-9-689-2012

Baradat P, Yasdani R (1988) Genetic expression for monoterpenes in clones of Pinus sylvestris grown on different sites. Scand J For Res 3:25-36 
Bullington LS, Lekberg Y, Sniezko R, Larkin B (2018) The influence of genetics, defensive chemistry and the fungal microbiome on disease outcome in whitebark pine trees. Mol Plant Pathol 19(8):1847-1858. https://doi.org/10.1111/mpp.12663

Chang S, Puryear J, Cairney J (1993) A simple and efficient method for isolating RNA from pine trees. Plant Mol Biol Report 11:113116. https://doi.org/10.1007/BF02670468

Clarke KR, Gorley RN (2006) PRIMER v6: user Manual/Tutorial. Plymouth Prime-E Ltd. https://doi.org/10.1111/j.1442-9993.1993. tb00438.x

Danielsson M, Lundén K, Elfstrand M et al (2011) Chemical and transcriptional responses of Norway spruce genotypes with different susceptibility to Heterobasidion spp. infection. BMC Plant Biol 11:154. https://doi.org/10.1186/1471-2229-11-154

Fäldt J, Martin D, Miller B et al (2003) Traumatic resin defense in Norway spruce (Picea abies): methyljasmonate-induced terpene synthase gene expression, and cDNA cloning and functional characterization of (+)-3-carene synthase. Plant Mol Biol 51:119-133. https://doi.org/10.1023/A:1020714403780

Franceschi VR, Krokene P, Christiansen E et al (2005) Anatomical and chemical defenses of conifer bark against bark beetles and other pests. New Phytol 167:353-375. https://doi.org/10.111 $1 / \mathrm{j} .1469-8137.2005 .01436 . \mathrm{x}$

Garbelotto M, Gonthier P (2013) Biology, epidemiology, and control of Heterobasidion species worldwide. Ann Rev Phytopathol 51:39-59. https://doi.org/10.1146/annurev-phyto-082712-102225

Gori Y, Cherubini P, Camin F, La Porta N (2013) Fungal root pathogen (Heterobasidion parviporum) increases drought stress in Norway spruce stand at low elevation in the Alps. Eur J For Res 132:607619. https://doi.org/10.1007/s10342-013-0698-x

Hall DE, Yuen MM, Jancsik S, et al (2013) Transcriptome resources and functional characterization of monoterpene synthases for two host species of the mountain pine beetle, lodgepole pine (Pinus contorta) and jack pine (Pinus banksiana). BMC Plant Biol 13:80. https://doi.org/10.1186/1471-2229-13-80

Han G (2019) Tansley review Origin and evolution of the plant immune system. New Phytol 222:70-83. https://doi.org/10.1111/ nph. 15596

Huber DPW, Bohlmann J (2006) The role of terpene synthases in the direct and indirect defense of conifers against insect herbivory and fungal pathogens. Multigenic Induc Syst Resist Plants. https://doi. org/10.1007/0-387-23266-4_13

Jaber E, Xiao C, Asiegbu FO (2014) Comparative pathobiology of Heterobasidion annosum during challenge on Pinus sylvestris and Arabidopsis roots: an analysis of defensin gene expression in two pathosystems. Planta 239:717-733. https://doi.org/10.1007/s0042 5-013-2012-z

Jactel H, Kleinhentz M, Marpeau-Bezard A et al (1996) Terpene variations in maritime pine constitutive oleoresin related to host tree selection by Dioryctria sylvestrella RATZ. (Lepidoptera: Pyralidae). J Chem Ecol 22:1037-1050. https://doi.org/10.1007/BF020 29953

Kainulainen P, Oksanen J, Palomäki V et al (1992) Effect of drought and water-logging stress on needle monoterpenes of Picea abies. Can J Bot 70:1613-1616. https://doi.org/10.1139/b92-203

Karlsson B, Tsopelas P, Zamponi L et al (2008) Susceptibility to Heterobasidion parviporum in Picea abies clones grown in different environments. For Pathol 38:83-89. https://doi.org/10.11 11/j.1439-0329.2008.00543.x

Katjiua MLJ, Ward D (2006) Resistance and tolerance of Terminalia sericea trees to simulated herbivore damage under different soil nutrient and moisture conditions. J Chem Ecol 32:1431-1443. https://doi.org/10.1007/s10886-006-9060-9

Keeling CI, Bohlmann J (2006) Genes, enzymes and chemicals of terpenoid diversity in the constitutive and induced defence of conifers against insects and pathogens. New Phytol
170:657-675. https://doi.org/10.1111/j.1469-8137.2006.01716 $\mathrm{x}$

Keriö S (2015) Terpene analysis and transcript profiling of the confier response to Heterobasidion annosum s.l. infection and Hylobius abietis feeding. PhD Thesis University of Helsinki, Finland. Hansaprint. ISSN 2342-5423. https://ethesis.helsinki.fi/

Keriö S, Niemi SM, Haapanen M et al (2014) Infection of Picea abies clones with a homokaryotic isolate of Heterobasidion parviporum under field conditions. Can J For Res 45:227-235. https://doi.org/10.1139/cjfr-2014-0247

Köpke D, Beyaert I, Gershenzon J et al (2010) Species-specific responses of pine sesquiterpene synthases to sawfly oviposition. Phytochemistry 71:909-917. https://doi.org/10.1016/j. phytochem.2010.03.017

Köpke D, Schroder R, Fischer HM et al (2008) Does egg deposition by herbivorous pine sawflies affect transcription of sesquiterpene synthases in pine? Planta 228(3):427-438. https://doi. org/10.1007/s00425-008-0747-8

Kovalchuk A, Kerï S, Oghenekaro AO et al (2013) Antimicrobial defenses and resistance in forest trees: challenges and perspectives in a genomic era. Annu Rev Phytopathol 51:221-244. https ://doi.org/10.1146/annurev-phyto-082712-102307

Kovalchuk A, Keriö S, Jaber E, et al (2015) Activation of defence pathways in Scots pine bark after feeding by Pine Weevil (Hylobius abietis). BMC Genomics 16:352. https://doi.org/10.1186/s1286 4-015-1546-9

Kovalchuk A, Zhu L, Keriö S, Asiegbu FO (2017) Differential responses of Scots pine stilbene synthase and chalcone synthase genes to Heterobasidion annosum infection. For Pathol 47:1-5. https://doi.org/10.1111/efp.12348

Livak KJ, Schmittgen TD (2001) Analysis of relative gene expression data using real-time quantitative PCR and the 2- $\Delta \Delta \mathrm{CT}$ method. Methods 25:402-408. https://doi.org/10.1006/meth.2001.1262

Lorenz WW, Ayyampalayam S, Bordeaux JM et al (2012) Conifer DBMagic: a database housing multiple de novo transcriptome assemblies for 12 diverse conifer species. Tree Genet Genomes 8:1477-1485. https://doi.org/10.1007/s11295-012-0547-y

Madmony A, Tognetti R, Zamponi L et al (2018) Monoterpene responses to interacting effects of drought stress and infection by the fungus Heterobasidion parviporum in two clones of Norway spruce. Environ Exp Bot 152:137-148. https://doi.org/10.1016/j. envexpbot.2018.03.007

Manninen AM, Tarhanen S, Vuorinen M, Kainulainen P (2002) Comparing the variation of needle and wood terpenoids in Scots pine provenances. J Chem Ecol 28(1):211-228

Metla (2013) Forest Finland in Brief. http://jukuri.luke.fi/bitst ream/handle/10024/529892/Forest-Finland_2013.pdf?seque nce $=1 \&$ isAllowed $=y$

Mukrimin M, Kovalchuk A, Neves LG et al (2018) Genome-wide exoncapture approach identifies genetic variants of Norway spruce genes associated with susceptibility to Heterobasidion parviporum infection. Front Plant Sci 9:793. https://doi.org/10.3389/ fpls.2018.00793

Muona O, Hiltunen R, Shaw DV, Moren E (1986) Analysis of monoterpene variation in natural stands and plustrees of Pinus sylvestris in Finland. Silva Fenn 20:1-8

Napierala-Filipiak A, Werner A, Mardarowicz M, Gawdzik J (2002) Concentrations of terpenes in mycorrhizal roots of Scots pine (Pinus sylvestris L.) seedlings grown in vitro. Acta Physiol Plant 24:137-143. https://doi.org/10.1007/s11738-002-0003-y

Nerg A-M, Heijari J, Noldt U et al (2004) Significance of wood terpenoids in the resistance of Scots pine provenances against the old house borer, Hylotrupes bajulus, and brown-rot fungus, Coniophora puteana. J Chem Ecol 30(1):125-141 
Nystedt B, Street NR, Wetterbom A et al (2013) The Norway spruce genome sequence and conifer genome evolution. Nature 497:579584. https://doi.org/10.1038/nature12211

Oliva J, Bendz-Hellgren M, Stenlid J (2011) Spread of Heterobasidion annosum s.s. and Heterobasidion parviporum in Picea abies 15 years after stump inoculation. FEMS Microbiol Ecol 75:414-429. https://doi.org/10.1111/j.1574-6941.2010.01020.x

Ott DS, Yanchuk AD, Huber DPW, Wallin KF (2011) Genetic variation of lodgepole pine, Pinus contorta var. latifolia, chemical and physical defenses that affect mountain pine beetle, Dendroctonus ponderosae, attack and tree mortality. J Chem Ecol 37:1002-1012. https://doi.org/10.1007/s10886-011-0003-8

Persson M, Sjödin K, Borg-Karlson AK et al (1996) Relative amounts and enantiomeric compositions of monoterpene hydrocarbons in xylem and needles of Picea abies. Phytochemistry 42:1289-1297. https://doi.org/10.1016/0031-9422(96)00119-7

Roach CR, Hall DE, Zerbe P, Bohlmann J (2014) Plasticity and evolution of (+)-3-carene synthase and (-)-sabinene synthase functions of a Sitka spruce monoterpene synthase gene family associated with weevil resistance. J Biol Chem 289:23859-23869. https:// doi.org/10.1074/jbc.M114.571703

Sniezko RA, Koch J (2017) Breeding trees resistant to insects and diseases: putting theory into application. Biol Invasions 19:33773400. https://doi.org/10.1007/s10530-017-1482-5

Sundell D, Mannapperuma C, Netotea S et al (2015) The plant genome integrative explorer resource: PlantGenIE.org. New Phytol 208:1149-1156. https://doi.org/10.1111/nph.13557

Swedjemark G, Karlsson B (2004) Genotypic variation in susceptibility following artificial Heterobasidion annosum inoculation of Picea abies clones in a 17-year-old field test. Scand J For Res 19:103-111. https://doi.org/10.1080/02827580310018032

Swedjemark G, Stenlid J (1995) Susceptibility of conifer and broadleaf seedlings to Swedish S and P strains of Heterobasidion annosum. Plant Pathol 44:73-79. https://doi.org/10.1111/j.1365-3059.1995. tb02717.x
Swedjemark G, Stenlid J (1996) Variation in spread of Heterobasidion annosum in clones of Picea abies grown at different vegetation phases under greenhouse conditions. Scand J For Res 11:137-144. https://doi.org/10.1080/02827589609382921

Thoss V, O'Reilly-Wapstra J, Iason GR (2007) Assessment and implications of intraspecific and phenological variability in monoterpenes of Scots pine (Pinus sylvestris) foliage. J Chem Ecol 33:477491. https://doi.org/10.1007/s10886-006-9244-3

Tiiva P, Häikiö E, Kasurinen A (2018) Impact of warming, moderate nitrogen addition and bark herbivory on BVOC emissions and growth of Scots pine (Pinus sylvestris L.) seedlings. Tree Physiol 38:1461-1475. https://doi.org/10.1093/treephys/tpy029

Vanhatalo A, Ghirardo A, Juurola E et al (2018) Long-term dynamics of monoterpene synthase activities, monoterpene storage pools and emissions in boreal Scots pine. Biogeosciences 15:50475060. https://doi.org/10.5194/bg-15-5047-2018

Vestman D, Larsson E, Uddenberg D et al (2011) Important processes during differentiation and early development of somatic embryos of Norway spruce as revealed by changes in global gene expression. Tree Genet Genomes 7:347-362. https://doi.org/10.1007/ s11295-010-0336-4

Villari C, Battisti A, Chakraborty S et al (2012) Nutritional and pathogenic fungi associated with the pine engraver beetle trigger comparable defenses in Scots pine. Tree Physiol 32:867-879. https:// doi.org/10.1093/treephys/tps056

Zamponi L, Michelozzi M, Capretti P (2007) Terpene response of Picea abies and Abies alba to infection with Heterobasidion s.1. For Pathol 37:243-250. https://doi.org/10.111 $1 /$ j.1439-0329.2007.00493.x

Publisher's Note Springer Nature remains neutral with regard to jurisdictional claims in published maps and institutional affiliations. 